\title{
A Short Analysis of Kate Chopin's A Respectable Women from a Feminist Perspective
}

\author{
Xin Liu \\ Hubei University of Science and Technology \\ Xianning, China
}

\begin{abstract}
Kate Chopin was an American author of short stories and novels based in Louisiana, who was considered by some literary critics to have been a forerunner of American 20th-century feminist authors. In her famous work $A$ Respectable Woman, she created a contradictory character and a brilliant and ambiguous closing. The thesis is aimed at discussing the feminist views and the reasons for extramarital love and the suggestions of contemporary marriage by revealing the oppression and resistance embodied in the story.
\end{abstract}

Keywords-feminism; oppression; resistance

\section{INTRODUCTION}

\section{A. Background and Purpose of the Analysis}

With the development of feminism, nowadays, women play an important role in politics, economy, education and family. They cannot only take part in various social activities, but also participate in the administration and discussion of state affairs. A growing number of scholars study the feminism works to find the theoretical foundation of the feminist movement.

After the publications of The Complete Works of Kate Chopin and A Critical Biography of Kate Chopin written by Per Seyersted, most scholars fixed attention on Kate Chopin. A Respectable Woman is one of Kate Chopin's masterpieces with unique language style, writing techniques and ambiguous themes, which offer a profound space to interpret. The story is just one thousand words, but it perfectly unveils the ups and downs of Mrs. Baroda's complex psychological process: courage and retreat, unrestrained and self-control, choice and helplessness, after she acquainted herself with her husband's friend Governail.

The ending of $A$ Respectable Woman is ambiguous. Mrs. Baroda's explanation "I have overcome everything" lefts an open ending whether the heroine suppresses her impulse or acts it out. (Yin Kangmin, 2005) Some think A Respectable Woman is a quite conservative and traditional story. Lin Jian and Wan Xuemei (2009) think that through nearly one year's psychological adjustment, the wife finally resists the temptation of extramarital love. Zhu Honglin (2010) argues that the wife intellectually protects her family and interprets what is a respectable woman with actions. Others hold that it is a feminist work, so the wife will overcome the constraint of traditional moral and pursue the true love. Guo Xiaolan (2009) points out that the story depicts the awakening of Mrs.
Baroda's self-consciousness which is a representation that southern women boldly abandon the traditional female moral and pursue their happy life.

As a forerunner of feminism, it is no doubt that Chopin's work can be studied from a feminist perspective. However, all of studies about A Respectable Woman from feminism perspective focus on the awakening of the wife's selfconsciousness, excluding the oppression in the story and the enlightenment for modern marriage.

Heroine's extramarital love can provide some suggestions to modern marriage. Readers can learn something from the heroine's marriage and establish a harmonious relationship with their mates.

\section{B. The Structure of the Thesis}

This thesis attempts to explore A Respectable Woman from a feminist perspective with the purpose to reveal the oppression and resistance embodied in the story as well as to give enlightenment for modern marriage.

The thesis consists of six parts with a brief introduction as beginning containing the background and purpose of the analysis with the literary review of $A$ Respectable Woman. Besides, it presents the structure of the thesis. Part two focuses on the critical research on Kate Chopin to analyze the reasons for Chopin to be a feminist writer from the social, family, marriage and education aspect as well as her feminist sensitivity in her work. Part three analyzes the oppression against women in the story. It explores not only the sources of oppression from the perspective of the patriarchal ideology, traditional moral and gendered division of labor, but also the reified oppression that woman has no voice, no libido and no identity. Part four is devoted to the resistance in the story. It explores the awakening of Mrs. Baroda's selfconsciousness and her struggle for the right to speak. Part five focuses on the enlightenment for modern marriage. It presents the importance of love, equality and economic independence. Part six draws a conclusion summarizing the main points and restating the theme of the thesis. 


\section{The BACKGROUnds OF KATE CHOPIN's FEMINIST TENDENCY}

\section{A. Background of the Times}

Kate Chopin (1851-1904) stepped on the American public stage in the late nineteenth century when more and more women were becoming committed to various kinds of social reforms, including their own social and political status. Chopin had grown up in a time when her surroundings included the abolitionist movements before the American Civil War, and their influence on freedmen education and rights afterward, as well as the emergence of feminism. Her ideas and descriptions were not reporting, but her stories expressed the reality of her world. Chopin took a strong interest in her surroundings and wrote about many of her observations. Jane Le Marquand assesses Chopin's writings as a new feminist voice, while other intellectuals recognize it as the voice of an individual who happens to be a woman.

\section{B. Background of the Family}

Kate Chopin was born in St.Louis in 1851 with a unique combination of French descendant and Irish origin. Because of her father's death, she grew up in a family of three independent women: her mother, her grandmother, and her great-grandmother, all of whom were tempered and refined by women of wisdom and ability. Chopin was usually entertained every night by hearing their varied tales of adventure and people, which later cultivated her gift on literature. (Cao Liang, 2013) Chopin's great-grandmother was the first woman in St.Louis who obtained a legal separation from her husband and Chopin's mother became the breadwinner to support and educate offspring after her father dead. All of them showed Chopin the female's strength and ability.

\section{The Marriage Reason}

In 1870, Chopin married Oscar, with whom she lived in his native New Orleans, and later on a plantation near Cloutiersvillele, Louisiana. Oscar had studied in France for a long time and been so deeply affected by French culture and education that he didn't strictly restrain his wife like other men. Naturally, Chopin had more freedom than other women. And she can maintain her unique life style: smoking cigarettes publicly, walking alone, riding alone and drinking beer. By every account, Kate Chopin loved her husband and had more free time to observe the world around her. She did not begin to write to support her family until after her husband's sudden death in 1883 at leaving her six children. She had always had a keen eye for detail and an equally sharp ear for the nuances of speech. Not surprisingly, in her fiction she shared this kind of image of women who try to pursue freedom, independence and true love.

\section{The Education Reason}

Kate Chopin was cultivated by the French culture and education from a young age and appreciated French writers, which made her deeply affected by French freedom consciousness. Her views of life were shaped by Maupassant, Whitman, Poe, Hawthorne and Emerson. Her work undoubtedly consists of the accumulation and essence of local color, romantic, transcendental and naturalistic movements. (Bai Ying, 2010) However, she surpasses these sources and struggles for finding her own perspective which calls for feminism. Chopin preserves her own direction in her long-suffering expedition though her voice is disapproved. Nowadays, Chopin and her work are shinning their brilliance in the American literary tradition.

\section{THE OPPRESSION IN A RESPECTABLE WOMEN}

\section{A. The Sources of Oppressions}

The source of oppression from a feminist perspective is various, but the most important factors are the patriarchal ideology, traditional morality and the gendered division of labor.

1) Oppression from the patriarchal ideology: Radical feminism insists that the patriarchy is the root of oppressing women. Women are objectified and subordinated by the traditional patriarchal ideology which maintains that father is the head of family. The patriarchal dualism insists that women are universalized as passive, emotional, sensitive and fragile human beings while men represent the active, mechanistic, intellectual, analytical and linear. (Bai Ying, 2010) In patriarchal society, women have acted as "other" for a long time. The bible claims that "she" as the first woman, comes from "a supernumerary rib" of Adam. Aristotle said that the women are merely tools and property at the free disposal of him. The great modern psychologist Freud explained woman as narcissistic, masochistic and less morally conscientious than man as well. Above all, woman is all that inferior to man, which sanctions men's supremacy over women.

2) Oppression from the traditional moral: Traditional moral, women are the embodiment of purity with the virtues of compassion, tolerance and patience. They are required to be perfect, obedient, gentle as well as pious. On the surface, they own the protection from men. In fact, they are treated without identity, rights and self. They are accessories and servants of men. They don't play the roles as women of true substance, but as daughters, wives and mothers who are under the control of men.

3) Oppression from the gendered division of labor: The main duties of women were restricted to family and other private sphere in the nineteenth century. Women's domestic labor which was consumed immediately was invisible and didn't produce any significant social benefits, so they relied on men's financial assistance, which resulted in women's subordinate position in the family.

\section{B. Oppression Is Embodied in "A Respectable Woman"}

1) The oppression of speaking right: Michel Foucault believes that the speaking right is closely connected with the power. One who obtains the speaking right can make a decision. In the story, Mrs. Baroda has no voice in her family at very beginning. "They had entertained lots of 
guests during the winter and spent much of the time in New Orleans varies forms of mild dissipation. She was looking forward to a period of unbroken rest, now, and undisturbed tete-a-tete with her husband." (Chopin, 1984) But, her husband insisted on inviting his friend to visit the plantation in spite of her opposition. What she wants is to stay alone with her husband but she has to entertain guests because hospitality was the virtue of Victorian women. Her desire and ideas are neglected and she can't arrange her own life on the basis of her interests and hobbies but her husband's aspiration. That is to say. She has no voice and self in her marriage.

2) The oppression of libido: Radical feminism also holds that sex is an important factor of men's oppression against women. Women's sexual desires are aroused for men. It was an important form of oppression against women in the nineteenth century that men had the definite right to control sex. Victorian ideal woman was a kind of woman without sexual desire and acted as sexual tools. In the story, Mrs. Baroda's husband didn't understand her and could never count upon how she was going to act under given conditions. And she did never feel those impulsions coming from Gouvernail when she was around her husband. She has a loveless marriage and has no libido in her marriage.

3) The oppression of individual identity: Mrs. Baroda has no identity in Gouvernail's eyes. At the very beginning, when Mrs. Baroda was eager to make Gouvernail feel at home, he just sat rather mute and receptive. "His manner was courteous toward her as the most exacting woman could require, but he made no direct appeal to her approval or even esteem."(Chopin, 1984) He does not regard her as Mrs. Baroda herself but as an ordinary respectable woman of the Victorian era. The heroine is a stereotype of Victorian women without individual identity.

\section{THE RESISTANCE EMBODIED IN A RESPECTABLE WOMAN}

Where there is oppression, there is resistance. Though the heroine is oppressive in her marriage, she gradually experiences her awakening of self-consciousness and struggles for the speaking right.

\section{A. The Awakening of Self-consciousness}

Mrs. Baroda lived a happy and rich life with a good family and a nice husband. She was a respectable woman following the traditional social ethics. But Gouvernail's visit disturbed her peace in mind. With the changes of her attitude towards to Gouvernail, her self-consciousness gradually awakened. The awakening can be divided into three stages: sprouts period, hesitation period and arousal stage.

Mrs. Baroda had heard much of but never seen Gouvernail. She had unconsciously formed an image of him in her mind. When they met, she found that he was not in conformity with her imagination. But she rather liked him when he first presented himself. "After a few days, when she could understand him no better than at first, she gave over being puzzled and remained piqued." (Chopin, 1894) As a traditional respectable woman, it is not necessary to pay so much attention to her guest. In sprouting period, she, as a woman, is attracted by another man.

His manner was as courteous toward her, but he made no direct appeal to her approval or even esteem. She attempted to draw his attention by keeping away from him for a while. However, Mr. Gouvernail hardly noticed her absence. So she turned to another way: "she imposed her company upon him, accompany him in his idle stroll in order to penetrate the reserve in which he had unconsciously enveloped himself."(Chopin, 1894) Nonetheless, it was also in vain. She was tremendously attracted to him and wanted to stay alone with him. On the other hand, she complained about him to her husband, pretending that she didn't like him. As a matter of fact, the depth of the attraction actually terrified her, because she had never experienced these feelings from her husband. She had a vague sense of what it represented: she seemed to fall in love with her husband's friend. As a married and respectable woman, this kind of feeling is deviation from the traditional moral. Her heart is full of conflicts.

In hesitation period, Mrs. Baroda is still a traditional woman whose behavior followed the traditional moral. In order to defend her family, she decided to go to her aunt's home to get rid of those forbidden feelings. But she had a subliminal physical attraction to Gouvernail in the night of their last encounter. In this beautiful and romantic night, she was determined to resist her passion for him, but this attempt was almost beyond her power.

"Her mind only vaguely grasped what he was saying. Her physical being was for the moment predominant. She was not thinking of his words but drinking the tone of his voice. She wanted to reach out her hand in the darkness and touch him with the sensitive tips of her fingers upon the face or the lips. She wanted to draw close to him and whisper against his cheek". (Chopin, 1984)

She has a strong desire to bring herself near him. Now, she is thoroughly awakened through the sexual desire of a woman was denied at that time. She is not her husband's sexual slavery any more and she can control her own desire.

\section{B. Mrs. Baroda's Struggle for the Right to Speak}

At the very beginning, Mrs. Baroda has no voice in her family. She has done everything for her husband's will. But gradually, she has her own voice. She complained about Gouvernail to her husband and expressed her displeasure. However, her complaint made no sense, and he would stay for a week, so she went to her aunt's home to express her protest. Then, her husband greatly desired to have his friend back during the summer that followed, which was yielded to her strenuous opposition. Her voice was heard. Finally, before the year ended, she proposed, wholly from herself, to have Gouvernail visit them again. In another word, she has her voice in her family in the end. 


\section{CONCLUSION}

As a productive and remarkable author who is ahead of her time in the nineteen century, Kate Chopin indeed puts the great concern about the life of the southern American women. She is quite a qualified writer with feminist awareness and sensitivity by revealing and criticizing the patriarchy which bears the root of domination over women. A Respectable Woman is one of her famous work with unique language style, writing techniques and controversial themes. It is worth studying.

The thesis attempts to combine feminism with the modern marriage. It analyzes Chopin's feminist sensitivity to her work and the oppression and resistance in the story. And most of all, it provides some suggestions to modern marriage: love, equality and economic independence.

However, the thesis just puts forward several suggestions lacking theoretical support to modern marriage. Besides, it doesn't point out temporary marital status. It lefts a large space to be explored for new arrivals to study the relationship between husband and wife from the feminist perspective.

\section{REFERENCES}

[1] Bai Ying (2010),From Homologous Oppression to Collaborative Republic: Xi'an Northwest University.

[2] Cao Liang (2013), The Reason Why Kate Chopin Became a Feminist Writer, [J]Economic \& Trade Update (10): 270-271.

[3] Chopin, K. (1894). A Respectable Woman. Vogue, 15-16.

[4] Colin G. Pooley, Siân Pooley. Constructing a suburban identity: youth, femininity and modernity in late-Victorian Merseyside[J]. Journal of Historical Geography, 2010, 36(4).

[5] Jin Li \& Qin Yaqing (1995), Repression, Awakening, Rebellion The Female Image in Kate Chopin, Foreign Literature(4): 58-63. 